\title{
Upaya Pemerintah Mempertahankan Posisi Sebagai Regulator Utama Penyiaran di Indonesia
}

\author{
Nina Mutmainnah \\ Departemen Ilmu Komunikasi Universitas Indonesia, \\ Fakultas Ilmu Sosial dan Ilmu Politik, Universitas Indonesia, Kampus UI Depok, \\ Jl. Prof. Dr. Selo Soemardjan, Depok, Jawa Barat 16424, Indonesia. \\ Email: n.mutmainah@ui.ac.id
}

\begin{abstract}
This study aims to examine the attitude of the government to maintain its position in the broadcast media system. Using the case study method, the author examined series of regulation of broadcasting, minutes of meeting, and media reporting on two broadcasting bill -- the Broadcasting Act of 1997, the Broadcasting Act of 2002and the revision of the Broadcasting Act on two parliament periods (2009 - 2014 and 2014 - 2019). The results of this study indicate the government is trying to maintain its position as the main regulator of broadcasting. Even though the Broadcasting Act of 2002 stipulates the Indonesian Broadcasting Commission (KPI) as the main regulator, the government still strives to be a broadcast regulator by giving birth to regulations that restore its position as the main regulator. This can be seen from the different standpoints in the two parliament periods in the revision of the Broadcasting Law: The 2009-2014 parliament strengthened the authority of the KPI, while the 2014-2019 parliament downgraded the KPI's authority and made the government the main regulator. The broadcast industry from the start wanted the government as the main regulator, while civil society rejected the government as the main regulator of broadcasting.
\end{abstract}

Keywords: Government, Indonesian Broadcasting Commission, main broadcasting regulator, Broadcasting Law, Revision of Broadcasting Law

\begin{abstract}
Abstrak. Penelitian ini bertujuan mengkaji sikap pemerintah untuk mempertahankan posisinya dalam sistem media penyiaran. Dengan metode studi kasus, peneliti mempelajari berbagai peraturan penyiaran, catatan rapat penyusunan UU, dan pemberitaan tentang regulasi penyiaran sejak masa UU Penyiaran pertama (UU No. 24/1997), UU Penyiaran (No. 32/2002), hingga revisi UU Penyiaran pada dua periode DPR (2009 - 2014 dan 20142019). Hasil penelitian ini menunjukkan pemerintah berusaha mempertahankan posisinya sebagai regulator utama penyiaran. Walaupun UU 32/2002 menetapkan Komisi Penyiaran Indonesia (KPI) sebagai regulator utama, pemerintah tetap berupaya menjadi pengendali penyiaran dengan melahirkan regulasi yang mengembalikan posisinya sebagai regulator utama. Ini dapat dilihat dari perbedaan sikap dalam dua periode DPR dalam revisi UU Penyiaran: DPR 2009-2014 menguatkan kewenangan KPI, sementara DPR 2014 - 2019 mengerdilkan kewenangan KPI dan menjadikan pemerintah sebagai regulator utama. Industri penyiaran sejak awal menginginkan pemerintah sebagai regulator utama, sedangkan masyarakat sipil menolak pemerintah sebagai regulator utama penyiaran.
\end{abstract}

Kata Kunci: Pemerintah, Komisi Penyiaran Indonesia, regulator utama penyiaran, UU Penyiaran, Revisi UU Penyiaran 


\section{Pendahuluan}

Tulisan ini memusatkan perhatian pada bagaimana pemerintah Indonesia berusaha mempertahankan posisinya sebagai regulator utama penyiaran. Kelahiran UU No. 32/2002 tentang Penyiaran sesungguhnya telah meminggirkan pemerintah sebagai pengendali utama penyiaran. Ini karena berdasarkan UU Penyiaran tersebut lahir regulator penyiaran di Indonesia yang merupakan wakil publik, yakni Komisi Penyiaran Indonesia (KPI). Setelah kelahiran UU Penyiaran 2002, di berbagai masa pemerintahan berbeda, pada dasarnya, terlihat pemerintah tetap berupaya menjadi pengendali sistem penyiaran dengan melahirkan serangkaian regulasi yang mengembalikan dan memperkuat posisinya sebagai regulator utama penyiaran.

Penulis berusaha menunjukkan bagaimana otoritas pemerintah sebagai pengendali utama dunia penyiaran dibangun dari kebijakan dan sikap yang dikeluarkan pemerintah (Departemen Penerangan/Deppen, Kementerian Negara Informasi dan Komunikasi atau Departemen/Kementerian Komunikasi dan Informatika atau Depkominfo/Kemenkominfo) sejak masa UU Penyiaran pertama (UU No. 24/1997), berlanjut ke proses lahirnya UU No. 32/2002 tentang Penyiaran, dan kemudian proses revisi UU Penyiaran (dua periode DPR: 2009 - 2014 dan 2014 - 2019). Dalam proses panjang ini, terdapat empat pemangku kepentingan yang terlibat, yakni (1) wakil rakyat/DPR, (2) KPI, (3) industri penyiaran, dan (4) masyarakat sipil yang masing-masing memiliki bentuk hubungan tersendiri dengan pemerintah dan jalinan tersendiri antar-pemangku kepentingan.
Sejumlah studi mengenai sistem media penyiaran pasca Orde Baru umumnya berpusat pada penguatan modal atau pasar dalam berperan menentukan arah penyiaran Indonesia. Sumbangan berharga tentang hal ini misalnya terlihat dari studi Sudibyo (2004), Triputra (2005), Armando (2006, 2011), Masduki (2007), Mufid (2007), Nugroho dkk (2012), dan Rianto dkk (2012, 2014). Berbeda dari studi sebelumnya yang berfokus pada basis kepentingan industri, studi ini menitikberatkan pada konsistennya pemerintah mengukuhkan otoritasnya dalam sistem penyiaran Indonesia yang didasari pada kepentingan politik dan ekonomi, baik berupa kepentingan pemerintah maupun pemangku kepentingan penyiaran lainnya.

Media penyiaran berjalan dengan menggunakan frekuensi siaran yang merupakan milik publik. Frekuensi disebut sebagai entitas yang menjadi wilayah kekuasan publik (Masduki, 2007). Spektrum frekuensi didefinisikan sebagai "rentang gelombang elektromagnetik yang dapat digunakan untuk penyiaran" (Zelezny, 2011). Dahlan (2012, dalam Mutmainnah, 2015) menjelaskan bahwa spektrum adalah sumber alam yang bersifat khusus dan esensial, bukan seperti sumber kekayaan alam fisik yang biasa diatur negara dalam konteks ekonomi. Ia adalah sumber alam yang nirfisik atau nirwujud (intangible); nilainya bukan terletak pada proses pengolahan yang membuatnya menjadi barang yang dapat dipakai habis, serta mempunyai nilai tertentu (seperti halnya dengan batubara, minyak bumi, bahan tambang, emas, dan sebagainya). Karena itu, sumber alam spektrum tidak dapat dinilai menurut ukuran industri biasa, atau diatur negara dalam konteks penghasilan ekonomi. Nilainya terletak pada cara penggunaan 
untuk kepentingan orang banyak secara merata dan bermanfaat.

Regulasi yang mengatur media penyiaran adalah regulasi yang ketat karena menggunakan ranah publik dan frekuensi itu terbatas. Apalagi, salah satu media penyiaran adalah televisi, yang siarannya dapat menembus ruang keluarga tanpa diundang.

Dunia penyiaran berbeda dengan dunia media cetak (pers). Bila media cetak (surat kabar dan majalah) tidak memerlukan izin terbit dan memiliki kebebasan penuh, hal yang sama tidak berlaku pada media penyiaran --media siaran dibatasi melalui beberapa peraturan penyiaran (lihat Frost, 2011; Menayang dalam Pandjaitan dan Sinaga, eds., 2000; Menayang dalam Gazali, et .al. eds., 2003). Media penyiaran harus memiliki izin penyiaran. Izin itu adalah keniscayaan karena hanya dengan cara itu lalu lintas penggunaan frekuensi siaran bisa berlangsung dengan tertib (Armando, 2011). Pertanyaannya, siapa yang mengeluarkan izin tersebut? Di sini diperlukan regulator.

Dalam negara demokrasi, regulasi media pada dasarnya diatur berdasarkan basis apakah media itu menggunakan ranah publik (public domain) atau tidak. Terdapat dua bentuk regulasi, yakni regulasi bagi media yang tidak menggunakan ranah publik dan menggunakan ranah publik. Media yang tidak menggunakan ranah publik (seperti film, surat kabar, majalah, dan buku) pengaturannya berupa pengaturan diri sendiri (self regulatory). Sementara itu, media yang menggunakan ranah publik (seperti media penyiaran: televisi dan radio) diatur sangat ketat atau highly regulated (Rahayu dkk, 2015). Siregar (2014) menyebut badan regulator yang mengatur media di ranah publik ini sebagai independent regulatory body, merupakan hal yang lumrah dalam negara demokratis. Forst (2011) menyebutnya sebagai statutory regulatory body, yakni lembaga regulator yang dibentuk berdasarkan undang-undang, didanai oleh uang publik, dan memiliki kewajiban serta wewenang hukum, tetapi bukan bagian dari pengadilan.

Dalam sistem penyiaran, di mana izin penggunaan frekuensi (milik publik) melekat di dalamnya, kehadiran regulator adalah suatu keniscayaan. Untuk menata dunia penyiaran, kehadiran lembaga otoritas yang memiliki hak untuk mengalokasikan frekuensi serta mencabut izin penyiaran hampir tak terhindarkan (Armando, 2011). Apalagi, lembaga otoritas ini dibutuhkan karena jumlah alokasi frekuensi terbatas. Dibutuhkan wasit yang adil dan demokratis untuk menjamin tersedianya, terdistribusikan, dan terawasinya ranah publik tersebut (Panjaitan, 2002, dalam Masduki 2007).

Regulator dalam sistem penyiaran diperlukan juga mengingat apa yang dinyatakan McQuail (1994). Ia menegaskan ada beberapa alasan awal mengapa penyiaran diatur jauh lebih ketat, yakni alasan teknis atau untuk memastikan alokasi sumber daya yang langka serta kontrol monopoli secara adil. Regulator penyiaran juga diperlukan karena kegiatan penyiaran yang menggunakan ranah publik berdampak luar biasa terhadap masyarakat. Dalam hal ini, menurut Siregar (2014), urusan penyiaran bukan saja berkaitan dengan distribusi frekuensi yang bersifat teknis, melainkan juga berhubungan dengan isi (content). Dengan demikian, menurutnya, pengaturannya harus sekaligus mencakup frekuensi dan isi berdasarkan prinsip diversity of content dan diversity of ownership untuk sebesarbesarnya kepentingan dan kebutuhan publik. Seiring dengan keyakinan mengenai diperlukannya regulator penyiaran, pada saat yang sama timbul 
kekhawatiran bila lembaga tersebut adalah pemerintah yang berkuasa. Pada masyarakat demokratis, timbul keyakinan bahwa pemerintah seharusnya tidaklah mengontrol kehidupan media karena adanya kekhawatiran bahwa kewenangan tersebut akan digunakan sebagai alat untuk membatasi pers. Padahal, pada negara demokratis, pers berperan sebagai alat kontrol pemerintah. Itulah sebabnya, di banyak negara demokratis, yang menjadi regulator utama penyiaran adalah lembaga negara independen (Siregar, 2014). Di banyak negara demokratis, lahir kebijakan untuk membentuk apa yang disebut sebagai lembaga negara yang dibentuk berdasarkan undang-undang (statutory body) yang berdiri independen, dan tidak menjadi bagian dari pemerintah (eksekutif) yang sedang berkuasa (Mutmainnah, 2015; Frost, 2011). Misalnya, Federal Communications Commission/FCC (Amerika), Office of Communication/Ofcom, Inggris), Australian Broadcasting Authority (Australia), Hong Kong Broadcasting Authority (Hong Kong), Broadcasting Authority of Ireland/BAI (Irlandia), dan Council Superieur de l'Audiovisuel/CSA (Perancis). Sebaliknya pada sejumlah negara dengan tingkat demokrasi lemah, kehadiran lembaga regulator di luar pemerintah belum bisa diterima; pada negara-negara ini, dunia penyiaran tetap berada pada kendali pemerintah.

Dalam konteks negara demokratis, sejumlah literatur menunjukkan bahwa badan regulator independen (independent regulatory body) merupakan regulator yang tepat untuk mengatur penyiaran. Menurut Grossberg dkk (2006 dalam Rahayu dkk, 2015), keberadaan badan regulator independen tersebut penting untuk mengantisipasi dua hal, yakni penyalahgunaan kekuasaan oleh negara atau pemerintah dan eksploitasi ekonomi oleh para pemilik kapital. Sementara itu
Llorens dan Costache (2014 dalam Rahayu dkk, 2015) menyatakan bahwa lembaga regulasi independen berperan penting untuk mempertahankan atau memperjuangkan pluralisme.

\section{Metode}

Penulis menggunakan metode studi kasus. Paparan mengenai upaya menegakkan otoritas pemerintah sebagai regulator utama penyiaran dari masa UU Penyiaran pertama hingga 2014 akan banyak merujuk pada disertasi penulis di Universitas Indonesia (2015). Adapun data untuk menggambarkan periode 2014 2019 diperoleh dari: (1) draf revisi UU Penyiaran yang dikeluarkan Komisi I dan Badan Legislasi (Baleg) dan (2) pemberitaan mengenai revisi UU Penyiaran.

\section{Hasil dan Pembahasan}

Untuk memudahkan penyajian hasil penelitian dan pembahasan, paparan dibagi secara kronologis. Dengan begitu, kemauan pemerintah untuk terus berusaha menjadi regulator penyiaran akan lebih mudah dianalisis dan dipetakan.

\section{UU Penyiaran Pertama: Pemerintah sebagai Pembina dan Pengendali Penyiaran}

UU Penyiaran pertama adalah UU No. 24/1997, yang lahir akibat dirasakan perlunya ada "regulasi payung" yang mengatur tentang penyiaran, terutama akibat pesatnya perkembangan radio dan TV (khususnya TV swasta yang lahir pada tahun 1989; lihat Mutmainnah, 2015). Sebelumnya, regulasi mengenai media penyiaran radio dan $\mathrm{TV}$ adalah regulasi dari segi perangkat keras, yakni UU No 5/1964 tentang Telekomunikasi yang kemudian diperbarui dengan UU No 
3/1989. Atas dasar UU tersebut lahir Peraturan Pemerintah dan Surat Keputusan Menteri Penerangan mengenai radio (termasuk mengenai pengaturan penyiaran radio siaran non-pemerintah). Untuk pengaturan mengenai TV, regulasinya berbentuk Keputusan Presiden untuk pendirian TVRI dan Surat Keputusan Menteri Penerangan untuk pendirian TV swasta.

UU Penyiaran pertama ini disahkan pada 18 September 1997, dan mencerminkan kuatnya pemerintah Orde Baru dan terutama sentralnya kekuasaan Presiden Soeharto. UU ini lahir melalui proses dua putaran (lihat Mutmainnah, 2015; Panjaitan, 1999; Masduki, 2007; Pandjaitan \& Sinaga, 2000; Armando, 2011). Putaran pertama dimulai dari proses awal kelahirannya, yakni dari adanya Rancangan UU (RUU) yang disampaikan pemerintah ke DPR 4 Maret 1996, DPR melakukan pembahasan RUU tersebut, hingga kemudian 9 Desember 1996 DPR meminta Presiden mengesahkan RUU tersebut menjadi UU. Presiden menolak menandatanganinya.

Pemerintah mengembalikan RUU tersebut kepada DPR berdasarkan instruksi yang datang dari Presiden Soeharto sendiri (Pandjaitan \& Sinaga, 2000; Armando, 2011).

Pengembalian RUU semacam ini belum pernah terjadi sebelumnya. Pengembalian RUU ini menyebabkan RUU ini masuk ke putaran kedua: DPR membahas kembali RUU ini dengan istilah "Penyempurnaan". Kondisi pembahasan putaran pertama dan putaran kedua RUU sangat berbeda. Jika pembahasan putaran pertama ditandai perdebatan seru untuk beberapa hal, pembahasan putaran kedua terkesan sebagai formalitas belaka. Hal ini disebabkan materi yang dibahas hanya sedikit dan sesuai dengan apa yang menjadi masukan pemerintah, selain pendeknya waktu yang tersedia. Pada waktu itu, tidak semua anggota DPR menyetujui pembahasan ulang putaran dua ini. Salah seorang anggota DPR yang kontra terhadap pembahasan ulang RUU ini menyatakan bahwa ia merasakan, terutama pada tahap pembahasan UU putaran kedua, lebih dominannya pemerintah dan pengusaha (Mutmainnah, 2015).

UU Penyiaran pertama ini memang menunjukkan kentalnya perspektif pemerintah, yang tidak terlepas dari sistem politik yang ada saat itu yang mengakomodasi kepentingan pengusaha. Penyusunan UU ini menunjukkan betapa kuatnya posisi TV swasta dalam penyusunan kebijakan. Sebenarnya, rancangan UU Penyiaran ini mengandung sejumlah muatan yang dapat ditafsirkan sebagai menantang kekuasaan para pemilik stasiun TV yang adalah keluarga dan kerabat Soeharto. UU ini dinilai otoriter. Dalam UU ini, dinyatakan bahwa pemerintah adalah pembina dan pengendali penyiaran. Dengan demikian, pemerintah berwenang penuh mengontrol segala aspek penyiaran. Dalam UU, memang dinyatakan bahwa dalam melaksanakan pembinaan dan pengendalian, pemerintah didampingi oleh $\mathrm{BP}_{3} \mathrm{~N}$ (Badan Pertimbangan dan Pengendalian Penyiaran Nasional). Namun, UU menegaskan peran $\mathrm{BP}_{3} \mathrm{~N}$ hanya sebagai pendamping dengan kewenangan terbatas, sementara kendali dunia penyiaran benar-benar berada di bawah pemerintah.

Hal lain dalam UU Penyiaran ini yang menunjukkan kuatnya kontrol pemerintah terlihat dari banyaknya ketentuan yang menyatakan bahwa ketentuan lebih lanjut mengenai berbagai aspek penyiaran diatur dengan Peraturan Pemerintah (PP). Paling tidak, terdapat 22 aspek penyiaran yang dinyatakan harus diatur lebih lanjut dengan PP. 
Satu hal yang perlu dicatat dari proses penyusunan UU Penyiaran pertama ini adalah adanya upaya dari sebagian anggota parlemen tentang perlunya demokratisasi media penyiaran di Indonesia. Pada pembahasan RUU putaran pertama, sudah ada upaya membuat ketentuan agar otoritas pemerintah tidak lagi terlalu besar untuk mengontrol sistem penyiaran. Disertasi penulis (2015) menyimpulkan bahwa dua contoh terbaik untuk ini adalah ketentuan mengenai badan regulator dan lembaga penyiaran publik. Pada RUU, sudah ada gagasan untuk melahirkan sebuah lembaga regulator bukan pemerintah dan gagasan agar TVRI dan RRI tidak lagi berada di jajaran Departemen Penerangan dan berdiri sebagai lembaga penyiaran yang lebih mandiri.

UU Penyiaran pertama ini tidak pernah berlaku. UU ini dinyatakan harus berjalan 29 September 1999. Namun, saat UU tersebut harus sudah efektif berlaku, tidak ada satu pun amanat UU tersebut dapat dijalankan. Apalagi kemudian, Departemen Penerangan dibubarkan (di masa Presiden Abdurrahman Wahid pada 1999), yang menyebabkan hilangnya operator terpenting UU ini. Itulah sebabnya ada yang mengibaratkan UU Penyiaran ini "sesungguhnya dia ada, tetapi sebenarnya belum pernah ada" (Pandjaitan \& Sinaga, 2000) atau "layu sebelum berkembang” (Masduki, 2007).

\section{UU Penyiaran No 32/2002: Lahirnya KPI, Regulator Baru}

Berbeda dari UU Penyiaran pertama, UU Penyiaran kedua (UU No 32/2002) disusun dengan semangat mereformasi dunia penyiaran. Semangat demokratisasi mewarnai jiwa UU ini, yang dilandasi oleh Reformasi 1998. Jika dilihat berdasarkan konteks politik kelahirannya, UU ini lahir dalam situasi yang sangat berbeda dengan UU Penyiaran sebelumnya. Saat ingin merevisi UU Penyiaran 1997, terdapat sentimen antinegara yang besar (Haryanto, 2014). UU Penyiaran 1997 dinilai mengandung semangat Orde Baru yang tidak lagi sesuai zaman.

Kelahiran UU Penyiaran kedua ini disambut gembira oleh masyarakat sipil. Dalam bentuk awalnya, UU Penyiaran 2002 merupakan hasil perjuangan masyarakat sipil untuk membangun sistem penyiaran yang demokratis. Melalui UU ini, urusan penyiaran menjadi urusan publik, tidak lagi sekadar urusan negara (dan bisnis) (Sudibyo, 2009). UU ini dinilai memberikan landasan bagi transformasi menuju sistem media penyiaran yang demokratis dan modern (Sudibyo, 2004).

DPR saat itu berkeinginan kuat melahirkan sebuah UU Penyiaran baru yang akan melemahkan kontrol pemerintah. Itulah sebabnya, dalam RUU Inisiatif DPR tersebut, tidak ada pasal "pembinaan dan pengendalian penyiaran". Hal ini tidak dapat diterima pemerintah. Pada masukan pemerintah terhadap RUU tersebut, pemerintah mengusulkan adanya penambahan bab baru tentang pembinaan, yang di dalamnya termaktub juga "pengendalian". Dapat dikatakan pemerintah tak mau beranjak dari ketentuan tentang "pembinaan dan pengendalian" yang ada pada UU No. 24/1997. Ketentuan ini mengundang perdebatan dalam proses penyusunan UU, yang kemudian berakhir dengan pemerintah mencabut sendiri usulannya itu.

UU Penyiaran 2002 melahirkan sebuah badan regulator baru yang independen bernama Komisi Penyiaran Indonesia (KPI). UU Penyiaran mendesain KPI sebagai sebuah super body yang mengatur dari hulu hingga hilir persoalan 
penyiaran di Indonesia (Judariksawan dalam Sudibyo, 2014).

Dalam proses penyusunan UU, pemerintah berusaha menolak gagasan DPR tersebut. Dalam tanggapannya terhadap RUU Penyiaran itu, pemerintah berupaya menjadikan KPI tidak independen dan bukan regulator tunggal. Oleh pemerintah, KPI dinyatakan sebagai "wujud peran serta masyarakat sebagai mitra pemerintah di bidang penyiaran". Pada dasarnya, pemerintah menolak gagasan kehadiran KPI sebagai lembaga pengatur penyiaran independen yang berada di luar stuktur pemerintahan.

Dalam proses penyusunan UU Penyiaran 2002, pandangan pemerintah mengenai regulator penyiaran mendapat dukungan dari industri penyiaran. Bahkan, lahirnya KPI sebagai lembaga regulator baru adalah salah satu hal yang ditakutkan pihak industri dari UU Penyiaran 2002 (Mutmainnah, 2015). Di pihak lain, lahirnya badan regulator independen yang diinisiasi oleh DPR disambut gembira oleh kelompok masyarakat sipil yang prodemokratisasi penyiaran.

Dalam catatan Sadono (2003 dalam Mutmainnah, 2015), aspek perizinan merupakan bidang di mana pemerintah merasa paling berkepentingan. Ketika proses penyusunan UU Penyiaran 2002, dengan mengatasnamakan kepentingan negara, pemerintah berusaha keras untuk tetap mengambil peran dalam sistem penyiaran. Pengendalian yang paling strategis adalah melalui perizinan, terutama dalam penggunaan frekuensi.

Kerasnya sikap pemerintah untuk tidak mau menyingkir dari gelanggang penyiaran tampaknya tak bisa dilepaskan dari sejarah lahirnya UU lain di era Reformasi. Sebelum UU Penyiaran 2002, di era Reformasi, telah lahir UU Pers (1999). UU Pers dinilai sangat demokratis karena memberi ruang penguatan masyarakat sipil yang besar dan meminggirkan pemerintah untuk tak lagi memegang kendali terhadap dunia media cetak. Berbekal pengalaman dari UU Pers yang membuat pemerintah kehilangan kewenangannya, dalam proses penyusunan UU Penyiaran, pemerintah berkeras untuk tetap memegang kendali penyiaran.

Persoalan mengenai siapa regulator penyiaran tercatat sebagai salah satu poin krusial yang diperdebatkan dalam proses penyusunan UU Penyiaran 2002. Jalan yang diambil kemudian adalah kompromi. Regulator penyiaran akhirnya ditetapkan berada di dua pihak: KPI dan pemerintah. Dalam UU No. 32/2002 ketentuan mengenai KPI dinyatakan dalam Pasal 7 12 dan Pasal 55. UU No. 32/2002 Pasal 7 ayat (2) menyatakan bahwa "KPI sebagai lembaga negara yang bersifat independen mengatur hal-hal mengenai penyiaran". Pada intinya, KPI adalah lembaga yang ditunjuk menjadi regulator utama (Mutmainnah, 2015). Kata "Pemerintah" tidaklah hilang dari UU Penyiaran. Dengan kata lain, pemerintah tetap berada dalam gelanggang pengaturan sistem penyiaran. Sebagai regulator penyiaran, KPI berbagi kewenangan dengan pemerintah. Dalam UU Penyiaran No. 32 tahun 2002, terdapat beberapa pasal yang menyatakan bahwa ketentuan lebih lanjut mengenai sejumlah aspek penyiaran harus ditetapkan oleh "KPI bersama-sama pemerintah". Selain itu, Pemerintah menjadi pihak yang bersama-sama KPI mengeluarkan Izin Penyelenggaraan Penyiaran. Armando (2011) mencatat, bagaimanapun, kalau dibaca isi UU, terlihat bahwa muatan tentang KPI sebenarnya jauh lebih dominan. Kesannya, KPI adalah pengendali utama, sementara pemerintah lebih dalam posisi menjaga jangan sampai KPI menjadi pemegang kekuasaan mutlak.

Di luar ketentuan tentang KPI, ada beberapa muatan penting dalam UU 
Penyiaran 2002 yang menunjukkan semangat demokratisasi. Disertasi penulis (2015) menyimpulkan beberapa muatan tersebut: (a) Diubahnya status TVRI dan $R R I$ dari lembaga penyiaran milik pemerintah menjadi lembaga penyiaran publik. Gagasan ini juga semula ditolak keras oleh pemerintah. (b) Diubahnya proses pemberian izin penyelenggaraan penyiaran menjadi transaparan, dimulai dari bawah (dari proses evaluasi dengar pendapat di KPI Daerah), dan pada akhirnya ditentukan melalui rapat bersama antara KPI dan pemerintah. Gagasan ini juga ditolak keras oleh pemerintah yang didukung industri penyiaran. (c) Diakuinya keberadaan Lembaga Penyiaran Komunitas yang merupakan sarana komunikasi yang demokratis bagi masyarakat. Gagasan ini ditolak oleh pemerintah dengan alasan kekhawatiran akan konflik horizontal. Penolakan ini juga didukung oleh industri penyiaran.

\section{Titik Balik: Judicial Review dan Lahirnya Peraturan Pemerintah}

Pada 28 Desember 2002, UU Penyiaran 32/2002 dinyatakan berlaku. Segera setelah itu, dibentuk KPI periode pertama. Tiga bulan sesudah KPI terbentuk, pada Maret 2003, enam organisasi mengajukan Judicial Review (JR) kepada Mahkamah Konstitusi (MK) untuk menggugat UU Penyiaran 2002 yang dianggap bertentangan dengan UUD 1945. Keenam organisasi tersebut adalah (1) Ikatan Jurnalis Televisi Indonesia (IJTI), (2) Persatuan Radio Siaran Swasta Nasional Indonesia (PRSSNI), (3) Persatuan Perusahaan Periklanan Indonesia (PPPI), (4) Asosiasi Televisi Siaran Indonesia
(ATVSI), (5) Persatuan Sulih Suara Indonesia (PERSUSI), dan (6) Komunitas Televisi Indonesia (KOMTEVE), diwakili oleh Gilang Iskandar. Organisasi yang paling berperan sebagai motor JR adalah ATVSI.

Pada Juli 2004, MK mengeluarkan keputusan yang berdampak sangat serius pada dunia penyiaran. MK memang menolak permintaan penggugat agar UU Penyiaran dibatalkan, tetapi dalam ketetapannya MK menyatakan KPI tidak lagi berwenang menjadi pihak yang bersama-sama pemerintah membuat peraturan pelaksanaan UU. MK menetapkan, anak kalimat "KPI bersama-sama..." harus dihilangkan dalam rangkaian ketentuan UU yang menyatakan bahwa ketentuan lebih lanjut harus ditetapkan oleh "KPI bersama-sama pemerintah". Implikasi ketetapan MK ini, maka yang berhak membuat ketentuan lebih lanjut hanya pemerintah. Kuasa hukum pihak pemohon JR menyatakan bahwa dengan putusan MK ini maka kewenangan KPI dalam membuat regulasi tidak lagi absolut karena kewenangan regulasi diserahkan sepenuhnya kepada Pemerintah (www.hukumonline.com, 28 Juli 2004). Putusan MK merupakan angin segar bagi pemerintah dan kalangan industri penyiaran. Namun, bagi KPI, secara signifikan, putusan itu menurunkan daya tawar KPI di hadapan pemerintah ataupun industri penyiaran. Khusus bagi industri penyiaran, keputusan MK untuk memangkas kewenangan regulatif KPI 
dinilai merupakan langkah maju tersendiri (Mufid, 2007).

Akibat ketetapan MK ini, terbukalah pintu lebar-lebar bagi kembalinya otoritas pemerintah dalam dunia penyiaran. Pada 2005, pemerintah mengeluarkan paket tujuh PP: (1) PP 11/2005 tentang Lembaga Penyiaran Publik, (2) PP 12/2005 tentang Lembaga Penyiaran Publik Radio Republik Indonesia, (3) PP 13/2005 tentang Lembaga Penyiaran Publik Televisi Republik Indonesia, (4) PP 49/2005 tentang Lembaga Penyiaran Asing, (5) PP 50/2005 tentang Penyelenggaraan Penyiaran Lembaga Penyiaran Swasta, (6) PP 51/2005 tentang Penyelenggaraan Penyiaran Lembaga Penyiaran Komunitas, dan (7) PP 52/2005 tentang Penyelenggaraan Penyiaran Lembaga Penyiaran Berlangganan. Dalam PP-PP tersebut, terdapat sejumlah ketentuan yang tidak sesuai dengan UU 32/2002, dan bertentangan dengan apa yang seharusnya menjadi kewenangan KPI yang telah diatur dalam UU 32/2002. Berbagai PP ini dibuat tanpa menyertakan KPI.

Disertasi penulis (2015) menunjukkan bahwa dalam proses penyusunan peraturan penyiaran di Indonesia berupa PP dan Permen terjadi apa yang disebut politisasi hukum. Merujuk pada Sadono (2007), politisasi hukum adalah suatu rekayasa, penyimpangan, atau penyelundupan hukum baik dalam proses pembuatan maupun penegakannya, yang dimanfaatkan untuk kepentingan di luar tujuan dan fungsi hukum itu sendiri sehingga melahirkan hukum yang tidak adil, tidak menjamin kepastian hukum, tidak sesuai dengan kebutuhan masyarakat. Politisasi hukum terjadi karena elite yang memegang kekuasaan selalu mempunyai kepentingan yang ingin dikukuhkan dalam bentuk produk hukum, sementara kontrol dari masyarakat, baik dari DPR, pers, dan lembaga kemasyarakatan yang lain sangat lemah. Secara teknis, bentuk politisasi hukum bisa melalui pasal-pasal dalam batang tubuh UU, tetapi juga bisa diselundupkan secara halus, misalnya, melalui peraturan pelaksanaan maupun aturan peralihan.

KPI periode pertama (2004 2007) melakukan upaya keras melawan kebijakan pemerintah untuk melahirkan PP. Salah satunya adalah mengajukan JR terhadap sejumlah PP ke Mahkamah Agung (2006), tetapi MA menolak permohonan KPI tersebut (2007). Upaya KPI mendapatkan dukungan dari sejumlah anggota DPR dan kelompok masyarakat sipil. Namun, pemerintah (dengan Menkominfo Sofyan Djalil) terus berkeras untuk memberlakukan PP-PP tersebut. Maka, PP pun dijalankan tanpa dapat ditahan. Apalagi, pada 2007, lahir keputusan MK atas permohonan KPI tentang sengketa kewenangan lembaga negara. Menurut MK, KPI dianggap tidak memiliki kedudukan hukum (legal standing) untuk mengajukan permohonan. Keputusan MK ini sangat memukul KPI (Armando, 2011).

Sejak saat itu, lahir serangkaian kebijakan pemerintah yang makin menunjukkan kokohnya kewenangan pemerintah dan sebaliknya melemahnya KPI. Kecenderungan pemerintah untuk tidak menyertakan KPI dalam pembuatan peraturan yang telah dimulai di era Menkominfo Sofyan Djalil terus berlanjut (Judhariksawan dalam Sudibyo, 2014). Kebijakan kontroversial belakangan yang dilahirkan Kemenkominfo adalah Peraturan Menteri (Permen) tentang digitalisasi di masa 2011 - 2013. Walau tidak dengan intensitas ketegangan yang sama seperti masa-masa KPI periode awal dulu, kebijakan pemerintah mengenai digitalisasi menjadikan hubungan KPI pemerintah bergejolak kembali. Pada 
2012, KPI mengeluarkan pendapat hukum (legal opinion) mengenai kebijakan digitalisasi Kemenkominfo. Penolakan terhadap Permen digital tidak hanya dilakukan oleh KPI, tetapi juga oleh DPR dan masyarakat sipil. Namun kembali pemerintah terus melaju dengan kebijakan ini.

Upaya KPI untuk menolak kebijakan pemerintah juga ditunjukkan pada kasus akuisisi atau merger PT Indosiar Karya Media Tbk (Indosiar) yang dilakukan PT Elang Mahkota Teknologi Tbk (EMTK), selaku induk usaha PT Surya Citra Media Tbk (SCTV) pada 2011.KPI menyatakan bahwa akuisisi ini melanggar UU Penyiaran 2002 dan menyampaikan legal opinion mengenai kasus ini kepada Kemenkominfo dan Badan Pengawasan Pasar Modal (www.kpi.go.id, 7 Juni 2011; www.beritasatu.com, 27 April 2011).

Di antara berbagai kebijakan tentang penyiaran yang dibuat pemerintah, memang ada regulasi yang kelahirannya didorong oleh KPI, tetapi jumlahnya sedikit sekali. Salah satunya kebijakan tentang kelonggaran bagi pendirian lembaga penyiaran komunitas di wilayah perbatasan dan/atau daerah tertinggal, yakni Permenkominfo No. 39/2012 tentang Tata Cara Pendirian dan Penyelenggaraan Penyiaran Lembaga Penyiaran Komunitas.

\section{Revisi UU Penyiaran: Periode 2009 - 2014}

DPR periode 2009 - 2014 mengajukan revisi UU Penyiaran, yang prosesnya dimulai pada 2010. Dari awal, tampak bahwa DPR berkeinginan merevisi UU Penyiaran antara lain karena kelemahan yang terkandung dalam UU 32/2202 yang membuat KPI kurang bergigi. Tampaknya, ada keinginan parlemen untuk kembali menguatkan posisi dan kewenangan KPI sebagai lembaga negara (lihat www.hukumonline. com, 19 Februari 2010).

Apa yang diniatkan oleh anggota DPR sejak awal RUU disusun terwujud. Pada akhirnya, DPR melahirkan sebuah RUU Inisiatif DPR (2012) yang kembali menegaskan kewenangan KPI. Dalam RUU ini, DPR mendefinisikan KPI sebagai "lembaga negara independen yang bertugas mengatur penyelenggaraan penyiaran". RUU menegaskan KPI berfungsi sebagai perwujudan hak publik dalam mengatur penyiaran di Indonesia. DPR membuat ketentuan tentang KPI dengan semangat demokrasi dengan menjadikannya sebagai independent regulatory body (Siregar, 2014). Seiring dengan memuat ketentuan yang memperbesar kewenangan KPI, RUU ini mengurangi kewenangan pemerintah.

Berlawanan dengan DPR yang kembali ingin menegaskan kewenangan KPI, pemerintah dalam tanggapannya terhadap RUU DPR justru meniadakan nama Komisi Penyiaran Indonesia (KPI), dan menggantinya dengan Komisi Pengawas Isi Siaran (KPIS). KPIS dinyatakan sebagai "lembaga independen yang bertugas dan berfungsi mengawasi isi siaran". Jadi, dengan mengganti nama KPI menjadi KPIS, tampak bahwa pemerintah mengerdilkan peran dan kewenangan lembaga negara ini dengan hanya mengurus isi siaran. Tidak hanya itu, pemerintah juga menegaskan bahwa segala hal mengenai KPIS diatur melalui PP dan mengusulkan seleksi anggota KPIS dilakukan berdasarkan proses rekrutmen oleh pemerintah dengan membentuk panitia seleksi yang terdiri dari unsur pemerintah dan masyarakat.

Usulan pemerintah tentang KPIS ini sebenarnya sejalan dengan apa yang sebelumnya diusulkan oleh sebagian anggota Tim Pakar Pendamping DPR yang 
membantu Komisi I DPR menyusun draft perubahan UU Penyiaran. Tim Pakar ini beranggotakan tujuh orang, yang dalam perjalanan menyusun draf DPR terbagi menjadi dua kelompok (beranggotakan tiga dan empat orang) yang tidak memperoleh titik temu dalam sejumlah isu penting, antara lain tentang regulator penyiaran. Tim Pakar tiga orang menyusun draf yang isinya berisi ketentuan tentang kewenangan KPI hanya terbatas mengurus isi siaran (draft tanpa nama penulis, disebut Draf Alternatif II; lihat Mutmainnah, 2015). Dalam draf ini pun termuat ketentuan bahwa KPI tidak memiliki kewenangan tunggal dalam menyusun aturan tentang isi siaran, tetapi harus menyusunnya bersama dengan asosiasi penyiaran, walau pada akhirnya aturan tersebut ditetapkan oleh KPI. Tim pakar ini adalah profesional penyiaran yang aktif di asosiasi penyiaran serta akademisi yang menjadi konsultan di lembaga penyiaran. Berlawanan dengan usulan tim tiga orang ini, tim pakar lainnya (empat orang, beranggotakan akademisi serta penggiat masyarakat sipil) menyusun draft yang menegaskan kewenangan KPI inilah ketentuan yang akhirnya diambil oleh DPR masuk dalam RUU Inisiatif.

Selain sejalan dengan usulan Draf Alternatif II, keinginan pemerintah untuk membatasi kewenangan KPI hanya di bidang pengawasan isi siaran juga serupa dengan gagasan pihak industri yang diajukan ATVSI dan MASTEL. Ini terlihat dari pernyataan kedua pihak ini saat rapat dengan DPR di akhir 2010.

Dalam proses revisi UU Penyiaran ini, juga terlihat jelas bahwa pemerintah tetap berkeinginan untuk menjadi pembina penyiaran. Setelah konsep "pembina penyiaran" lahir di UU Penyiaran pertama (1997) dan berusaha dimunculkan kembali saat proses penyusunan UU Penyiaran 2002, maka pemerintah kembali memunculkannya melalui tanggapannya atas RUU. Pemerintah menyatakan bahwa pembinaan penyiaran dilakukan oleh pemerintah, yang meliputi: penetapan kebijakan, pengaturan, pengawasan, dan pengendalian, yang bertujuan untuk meningkatkan kualitas penyelenggaraan penyiaran.

Demikian dominannya kewenangan pemerintah dalam RUU versi pemerintah ini, Siregar (2014) menyebut RUU versi pemerintah bersifat chauvinis dan otoritarian. Pemerintah menjadi regulator utama yang dominan: sebagai pembuat kebijakan, pengaturan, pengawasan, dan pengendalian, memotong peranan KPI.

UU Penyiaran baru pada akhirnya tidak pernah lahir pada periode ini karena sampai masa tugas DPR berakhir di 2014, proses revisi UU ini tidak selesai.

\section{Revisi UU Penyiaran: Periode 2014 - 2019}

DPR periode 2014 - 2019 kembali mengajukan revisi UU Penyiaran. Hingga Maret 2019, revisi UU Penyiaran 2002 sudah selesai dibahas di Komisi I DPR RI dan berada di tangan Badan Legislasi atau Baleg. RUU versi DPR ini rencananya akan disahkan pada Oktober 2017, tetapi pengesahan tertunda akibat terjadi kebuntuan (deadlock) pada rapat gabungan antara Baleg dan pengusul (Komisi I) DPR 3 Oktober 2017. Ketidaksepakatan terjadi dalam penentuan penyelenggaraan multiplekser (mux) dalam penyiaran digital (www.tempo.co, 12 Oktober 2017; www.tempo.co,24 Mei 2018; www.kompas.com, 27 November 2018). Walaupun setelah Oktober 2017 terdapat kabar adanya beberapa kali rapat koordinasi antara pimpinan DPR, pimpinan Komisi I, dan pimpinan Baleg 
secara tertutup (www.tempo.co, 5 April 2018), namun hingga Maret 2019 belum ada pengesahan terhadap RUU Inisiatif DPR.

Berbeda dari digitalisasi, penetapan mengenai regulator penyiaran bukanlah isu yang diperdebatkan dalam penyusunan RUU Penyiaran pada periode ini. Berbeda dengan DPR 2014-2019 yang dinilai mengusung demokratisasi penyiaran, antara lain karena menetapkan KPI sebagai regulator utama, DPR periode ini sejak awal telah menetapkan KPI hanya mengurus isi siaran. Dalam draf DPR 3 Oktober 2017 (draf Baleg) dinyatakan "KPI adalah lembaga negara yang bersifat independen yang bertugas mengatur isi siaran”. Ketentuan draf Baleg ini sesungguhnya tidak pernah berubah dari sejak awal draf dibuat oleh Komisi I.

Persoalan mengenai kewenangan KPI adalah salah satu faktor penting dalam merevisi UU. Dalam Naskah Akademis RUU Penyiaran tertanggal 2 Februari 2016, dinyatakan bahwa urgensi penggantian UU Penyiaran di antaranya: "terdapat pasal yang menimbulkan multitafsir, antara lain pasal mengenai kewenangan KPI...”

Draf DPR 3 Oktober 2017 memberikan kewenangan yang sangat besar kepada pemerintah untuk mengatur dunia penyiaran. Pemerintah adalah pihak yang memiliki otoritas antara lain dalam Rencana Induk Penyiaran (Pasal 5 ayat 2), menentukan arah kebijakan Sistem Penyiaran Nasional (Pasal 11 ayat 1 huruf a), menetapkan pemetaan penggunaan frekuensi penyiaran (Pasal 11 ayat 1 huruf b), dan hal-hal terkait izin penyelenggaran penyiaran (Pasal 11 ayat 1 huruf $\mathrm{c}-\mathrm{f}$ ).

Dengan ketentuan tersebut,
tampak jelas bahwa sejak awal
penyusunan RUU sudah ada kesamaan
antara DPR dan pemerintah mengenai
siapa yang menjadi regulator utama.

Sikap ini juga sejalan dengan kemauan industri penyiaran yang sejak awal menginginkan pemerintah sebagai regulator utama, bukan KPI -bahkan usulan awal mengenai KPI hanya mengurus isi siaran juga berasal dari asosiasi industri penyiaran.

Kesamaan pandangan antara DPR dan pemerintah mengenai kewenangan KPI terlihat dari pernyataan Menkominfo Rudiantara saat menjelaskan penyebab pemerintah ingin merevisi UU Penyiaran. Menkominfo menegaskan, selain persoalan digitalisasi, faktor lain yang membuat pemerintah ingin merevisi UU Penyiaran adalah "Mereposisi peran dari KPI, hingga betul-betul kembali kepada pengawasan manajemen konten" (www.beritasatu.com, 2 April 2018).

Pada 2017, KPI memberi masukan untuk RUU Penyiaran kepada DPR (www.kpi.go.id, 14 Juli 2017). Salah satu masukan adalah tentang eksistensi KPI, yakni: "Eksistensi Komisi Penyiaran Indonesia sebagai representasi publik perlu diperkuat dalam undang-undang penyiaran yang akan datang. Penguatan itu meliputi perluasan kewenangan di bidang isi siaran serta tetap melibatkan KPI di dalam seluruh proses penataan infrastruktur penyiaran untuk mengontrol kaidah pokok demokratisasi penyiaran, yakni keberagaman kepemilikan (diversity of ownership)". Dari masukan ini, tidak terlihat sama sekali ketegasan KPI untuk menyebut lembaganya sebagai regulator utama penyiaran dan seharusnya mengatur dunia penyiaran lebih dominan dibandingkan pemerintah.

Ketidaktegasan atau ketiadaan sikap gigih yang ditunjukkan KPI untuk menjadikan lembaganya memperoleh kewenangan yang lebih besar juga tampak pada beberapa pemberitaan mengenai masukan atau harapan lembaganya terhadap RUU Penyiaran. Ketika terjadi 
deadlock dalam proses penyusunan RUU Penyiaran, seorang anggota KPI misalnya berkomentar, "Perdebatan-perdebatan yang ada di DPR diharapkan tidak merugikan kewenangan KPI sebagai pengawas konten dalam penyiaran" (www.sindonews.com, 21 Oktober 2017). Dalam contoh lain, Ketua KPI menyakini bahwa revisi UU akan memperkuat kewenangan lembaganya. Yang dimaksudkannya adalah, "KPI hanya akan mengurus siaran, tidak lagi memperpanjang izin televisi dan radio. KPI akan berdiri secara independen, diperkuat, sekjen tidak lagi berdiri di bawah Kementerian Komunikasi dan Informatika" (www.cnnindonesia.com, 30 Januari 2017). Dengan berkomentar seperti ini, terlihat bahwa para komisioner KPI sendiri menilai lembaganya memang hanya punya kewenangan untuk mengurus isi siaran.

Istilah "memperkuat KPI" atau "penguatan KPI" memang jadi jargon yang seringkali dikemukakan dalam berbagai kesempatan baik oleh pemerintah maupun anggota DPR. Padahal, kalau dicermati, yang dimaksudkan itu hanya penguatan dalam hal pengawasan isi siaran. Sebagai contoh, anggota Komisi I Elnino Mohi dalam seminar 15 November 2017 menyatakan bahwa draf RUU menyepakati adanya penguatan kelembagaan KPI sebagai instrumen negara yang bertanggungjawab melakukan pengawasan terhadap kualitas isi siaran (www.kpi.go.id, 16 November 2017).

Ketentuan yang mengerdilkan posisi dan kewenangan KPI dalam RUU sejak awal dikritik oleh masyarakat sipil. Kritik gencar disuarakan oleh KNRP (Koalisi Nasional Reformasi Penyiaran), sebuah koalisi akademisi-penggiat masyarakat sipil yang didirikan April 2016. Masyarakat sipil mengkritik ketentuan tentang minimnya peran KPI dan sebaliknya peran dominan penyiaran yang dipegang pemerintah (www.kompas.com, 21 April 2016; www.tirto.id, 29 Desember 2016).

KNRP melihat terdapat banyak kesamaan antara draf Baleg dan apa yang diminta ATVSI (www.kompas.com, 17 September 2017). Ini tidak mengherankan mengingat Ketua ATVSI sendiri menyatakan bahwa ATVSI telah diundang Baleg pada 3 April 2017 untuk memberikan tanggapan dan masukan mengenai beberapa isu penting yang menjadi roh dari RUU Penyiaran. ATVSI juga menyampaikan naskah akademik dan draft RUU kepada Baleg dan Panja RUU Penyiaran DPR RI (www.kompas.com, 5 Mei 2017). Dalam masukannya, ATVSI menyampaikan tujuh isu krusial terkait RUU Penyiaran. Masalah kewenangan regulator penyiaran bukanlah isu yang dinilai krusial oleh ATVSI, kemungkinan karena sejak awal draf DPR telah menetapkan ketentuan bahwa regulator utama adalah pemerintah, sesuai dengan yang diharapkan ATVSI sejak proses UU Penyiaran 2002 disusun.

\section{Penutup}

UU No. 32/22002 tentang Penyiaran sesungguhnya telah menetapkan regulator utama penyiaran adalah KPI dan bukan pemerintah. UU ini membawa semangat demokratisasi karena meletakkan daulat penyiaran ada pada tangan publik (melalui KPI), sejalan dengan media penyiaran yang berjalan dengan menggunakan frekuensi siaran yang merupakan milik publik.

UU Penyiaran 2002 mengubah UU Penyiaran sebelumnya yang dinilai otoriter, yang meletakkan kendali penyiaran berada sepenuhnya di tangan pemerintah. Adanya keputusan MK mengenai Judicial Review UU Penyiaran 2002 menjadi titik balik yang 
mengembalikan kewenangan pemerintah sebagai regulator utama.

Dari implementasi UU Penyiaran 2002 dalam 17 tahun perjalanannya (2002 - 2019), terlihat berbagai kebijakan dan upaya untuk mengembalikan daulat penyiaran bukan di tangan KPI, melainkan kembali di tangan pemerintah. Pada 2005, pemerintah mengeluarkan paket tujuh PP yang ditolak oleh KPI periode pertama. Upaya KPI gagal dan selanjutnya tanpa bisa ditahan pemerintah mengeluarkan serangkaian kebijakan yang makin menunjukkan kokohnya kewenangannya.

Upaya untuk mengembalikan kewenangan pemerintah sebagai regulator utama tidak hanya terwujud dari berbagai kebijakan yang dilahirkan oleh pemerintah sendiri (dengan mengeluarkan kebijakan yang meminggirkan KPI hanya mengurusi isi siaran), tetapi juga belakangan oleh DPR yang di periode 2014 - 2019 melahirkan draft revisi UU Penyiaran yang mengerdilkan kewenangan KPI dan sebaliknya memberikan dominasi kewenangan yang sangat besar kepada pemerintah dalam mengatur sistem penyiaran. Draf DPR terakhir di periode ini (draf 3 Oktober 2017) menyatakan kewenangan yang sangat besar kepada pemerintah untuk mengatur dunia penyiaran, antara lain mengatur Rencana Induk Penyiaran, arah kebijakan Sistem Penyiaran Nasional, pemetaan penggunaan frekuensi penyiaran, dan halhal terkait izin penyelenggaran penyiaran.
Dengan demikian, dapat disimpulkan bahwa sejak awal penyusunan RUU sudah ada kesamaan antara DPR dan pemerintah mengenai siapa yang menjadi regulator utama penyiaran.

Tampaknya, masyarakat sipil yang sejak awal kelahiran UU Penyiaran 2002 mengharapkan sebuah UU Penyiaran yang demokratis masih harus terus berjuang agar di Indonesia lahir sebuah UU Penyiaran yang demokratis, yang meletakkan kewenangan regulator utama penyiaran berada di tangan publik, bukan pemerintah. Di sisi lain, justru inilah yang ditolak oleh kalangan industri penyiaran. Sebagaimana keinginan mereka sejak lahirnya UU Penyiaran, industri penyiaran tetap menginginkan pemerintah berada dalam gelanggang sistem penyiaran mereka tidak menginginkan dominasi kewenangan regulasi lepas dari tangan pemerintah.

$$
\text { Berpegang pada prinsip }
$$
demokratisasi penyiaran, peneliti menyimpulkan seharusnya posisi regulator utama penyiaran tidak dipegang oleh pemerintah, melainkan oleh wakil publik yang independen sebagaimana semangat yang dibawa oleh UU No. 32/2002 tentang Penyiaran. Oleh karena itu, dalam revisi UU Penyiaran mendatang, untuk menjaga prinsip demokratisasi penyiaran, posisi regulator utama penyiaran harus diletakkan pada KPI dengan hak dan kewenangan yang besar sebagai wakil publik yang mengatur penyiaran. 


\section{Daftar Pustaka}

Armando, Ade. (2011). Televisi Jakarta di Atas Indonesia: Kisah Kegagalan Sistem Televisi Berjaringan di Indonesia. Yogyakarta: Bentang.

(2006). "Privatisasi Pertelevisian Indonesia: Antara Dinamika Internal dan Perkembangan Global”. Disertasi Bidang Ilmu Komunikasi Program Pascasarjana FISIP UI.

"ATVSI Usulkan Tujuh Isu Krusial Terkait Revisi UU Penyiaran", www.kompas.com, 5 Mei 2017; https://nasional.kompas.co $\mathrm{m} / \mathrm{read} / 2017 / 05 / 05 / 15251371 / \mathrm{atv}$ si.usulkan.tujuh.isu.krusial.terkait. revisi.uu.penyiaran, diakses 7 April 2019.

"Bahas RUU Penyiaran, DPR Rapat dengan Kominfo Minggu Depan",www.tempo.co, 5 April 2018,https://bisnis.tempo.co/read $\not 1076735 /$ bahas-ruu-penyiarandpr-rapat-dengan-kominfominggu-depan, diakses 7 April 2019.

"Dewan Pers: Kami Tak Dilibatkan dalam Revisi UU Penyiaran”, 27 November 2008, https://nasional. kompas.com/read/2018/11/27/05 242651/dewan-pers-kami-takdilibatkan-dalam-revisi-uupenyiaran, diakses 7 April 2019.

"Draf RUU Penyiaran Dinilai Lebih Menguntungkan Industri Televisi", www.kompas.com, 17 September 2017, https://nasional. kompas.com/read/2017/09/17/17 272941/draf-ruu-penyiarandinilai-lebih-menguntungkanindustri-televisi?page $=$ all, diakses 7 April 2019.
Frost, Chris. (2011). Journalism Ethics and Regulation. Harlow: Pearson Education Limited.

Gazali, Effendi. et.al. eds. (2003). Konstruksi Sosial Industri Penyiaran. Jakarta: Departemen Ilmu Komunikasi FISIP UI.

Haryanto, Ignatius. (2014). Jurnalisme Era Digital: Tantangan Industri Media Abad 21. Jakarta: Kompas.

"Kemenko Polhukam Akan Kawal Revisi RUU Penyiaran", www.tempo.co, 24 Mei 2018, https://bisnis.tempo.co/read/1092 154/kemenko-polhukam-akankawal-revisi-ruupenyiaran/full\&view=ok diakses 7 April 2019.

"Komisi I DPR Pastikan Penguatan KPI dalam RUU Penyiaran yang Baru”, www.kpi.go.id, 16 November 2017 , http://www.kpi.go.id/index.php/i d/umum/38-dalam-negeri/34185komisi-i-dpr-pastikan-penguatankpi-dalam-ruu-penyiaran-yangbaru, diakses 7 April 2019.

"KPI Keluarkan Opini Hukum Terkait Akuisisi Indosiar" www.beritasatu.com, 27 April 2011, https://id.beritasatu.com/home/k pi-keluarkan-opini-hukum-terkaitakuisisi-indosiar/10624, diakses 6 April 2019.

"KPI Minta DPR Segera Selesaikan Pembahasan RUU Penyiaran", www.sindonews.com, 21 Oktober 2017, https://nasional.sindonews. com $/ \mathrm{read} / 1250518 / 12 / \mathrm{kpi}$-mintadpr-segera-selesaikanpembahasan-ruu-penyiaran1508595735, diakses 7 April 2019. 
"KPI Sampaikan Delapan Isu Krusial dalam Revisi UU Penyiaran", www.kpi.go.id, 12 Juli 2012, http://www.kpi.go.id/index.php/i d/umum/30652-kpi-sampaikandelapan-isu-krusial-dalam-revisiuu-penyiaran, diakses 7 April 2019.

"KPI Sampaikan Masukan tentang RUU Penyiaran", www.kpi.go.id.23 Maret 2017, http://www.kpi.go.id/index.php/i d/umum/38-dalam-negeri/33852kpi-sampaikan-masukan-tentangruu-penyiaran, diakses 26 Maret 2017.

Masduki. (2007). Regulasi Penyiaran: Dari Otoriter ke Liberal. Yogyakarta: LKiS.

Mufid, Muhammad. (2007). Komunikasi dan Regulasi Penyiaran. Jakarta: Kencana Prenada Media Group.

Mutmainnah, Nina. (2015). "Kontrol Pemerintah dalam Sistem Media Penyiaran: Studi Ekonomi Politik tentang Upaya Pemerintah Mengembalikan dan Menegakkan Kewenangannya dalam Peraturan Perundangan di Bidang Penyiaran. Disertasi Program S3 Ilmu Komunikasi UI.

Mufid, Muhammad. (2007). Komunikasi dan Regulasi Penyiaran. Jakarta: Kencana Prenada Media Group.

Nugroho, Yanuar, Siregar, dan Shita Laksmi. (2012). Memetakan Kebijakan Media di Indonesia (Edisi Bahasa Indonesia). Laporan. Bermedia, Memberdayakan Masyarakat: Memahami kebijakan dan tatakelola media di Indonesia melalui kacamata hak warga negara. Kerjasama riset antara Centre for Innovation Policy and Governance dan HIVOS Kantor Regional Asia Tenggara, didanai oleh Ford Foundation. Jakarta: CIPG dan HIVOS.
Panjaitan, Hinca. (1999). Memasung Televisi: Kontroversi Regulasi Penyiaran di Era Orde Baru. Jakarta: Institut Studi Arus Informasi.

dan Cahaya Sinaga, eds. 2000. Penyiaran 2000: Aspek Regulasi dan Kebijakan. Prosiding Seminar. Jakarta: Internews Indonesia.

"Pandangan Hukum KPI atas Rencana Aksi Korporasi PT INDOSIAR KARYA MEDIA TBK oleh PT ELANG MAHKOTA TEKNOLOGI TBK", www.kpi.go.id, 7 Juni 2011, http://www.kpi.go.id/index.php/i d/siaran-pers/3038-pandanganhukum-kpi-atas-rencana-aksikorporasi-pt-indosiar-karyamedia-tbk-oleh-pt-elang-mahkotateknologi-tbk, diakses 7 April 2019.

"Revisi UU Penyiaran Disebut Akan Perkuat Kewenangan KPI", www.cnnindonesia.com, 30 Januari 2017, https://www. cnnindonesia.com/nasional/2017 0130234131-20-190159/revisi-uupenyiaran-disebut-akan-perkuatkewenangan-kpi, diakses 7 April 2019.

"Revisi UU Penyiaran, Lembaga Penyiaran Raksasa Diduga Bermain”, 12 Oktober 2017, https://nasional.tempo.co/read/10 24017/revisi-uu-penyiaranlembaga-penyiaran-raksasadiduga-bermain, diakses 7 April 2019.

McQuail, Denis. (1994). McQuail's Mass Communication Theory. London: Sage Publications.

Rahayu, dkk. (2015). Menegakkan Kedaulatan Telekomunikasi dan Penyiaran di Indonesia. Yogyakarta: Pr2Media dan Yayasan TIFA. 
"Revisi UU Penyiaran Dianggap Alami Kemunduran, Ini Alasannya", www.kompas.com, 21 April 2016, https://nasional.kompas.com/rea $\mathrm{d} / 2016 / 04 / 21 / 22461921 /$ Revisi. UU.Penyiaran.Dianggap.Alami.Ke munduran.Ini.Alasannya, diakses 7 April 2019.

Rianto, Puji, et.al. (2014). Kepemilikan dan Intervensi Siaran: Perampasan hak Publik, Dominasi, dan Bahaya Media di Tangan Segelintir Orang. Yogyakarta: PR2Media dan Yayasan TIFA.

(2012a). Digitalisasi Televisi di Indonesia: Ekonomi Politik, Peta Persoalan, dan Rekomendasi Kebijakan. Yogyakarta: PR2Media dan Yayasan TIFA. (2012b). Dominasi TV Swasta (Nasional): Tergerusnya Keberagaman Isi dan Kepemilikan. Yogyakarta: PR2Media dan Yayasan TIFA.

"Rudiantara: Digitalisasi Faktor Revisi UU Penyiaran", www.beritasatu.com, 2 April 2018, https://id.beritasatu.com/home/r udiantara-digitalisasi-faktorrevisi-uu-penyiaran/173924, diakses 9 April 2019.

Siregar, Amir Effendi. (2014). Mengawal Demokratisasi Media: Menolak Konsentrasi, Membangun Keberagaman. Jakarta: Kompas.

"Sembilan Poin Keberatan KNRP pada Draf Revisi UU Penyiaran", 29 Desember 2016, https://tirto.id/ sembilan-poin-keberatan-knrppada-draf-revisi-uu-penyiaranccMX, diakses 6 April 2019.
Sudibyo, Agus, ed. (2014). SBY dan Kebebasan Pers: Testimoni Komunitas Media. Jakarta: Persatuan Wartawan Indonesia (PWI).

(2009). Kebebasan Semu: Penjajahan Baru di Jagat Media. Jakarta: Kompas.

Politik
$\begin{aligned} & \text { Yogyakarta: LKiS dan ISAI. } \\ & \text { Media }\end{aligned}$

Triputra, Pinckey. (2005). "Dilema Industri Penyiaran di Indonesia: Studi tentang Neoliberisme di Era Orde Baru dan Reformasi”. Disertasi Bidang Ilmu Komunikasi Program Pascasarjana FISIP UI. "Undang-Undang Penyiaran yang Baru Harus Mengutamakan Kepentingan Publik”, www.kpi.go.id, 14 Juli 2017, http://www.kpi.go.id/index.php/i d/umum/38-dalam-negeri/34029undang-undang-penyiaran-yangbaru-harus-mengutamakankepentingan-publik, diakses 7 April 2019.

"Urgensi Revisi UU Penyiaran Dipersoalkan", www.hukumonline.com, $\quad 19$ Pebruari 2010, https://www. hukumonline.com/berita/baca/lt4 b7e550d5701e/revisi-uupenyiaran, diakses 6 April 2019.

Zelezny, John D. (2011). Communications Law: Liberties, Restraints, and the Modern Media. Boston: Wadsworth.

-MK Pangkas Kewenangan Regulasi Komisi Penyiaran Indonesia", www.hukumonline.com, 28 Juli 2004,

https://www.hukumonline.com/be rita/baca/hol10830/mk-pangkaskewenangan-regulasi-komisipenyiaran-indonesia/. 
Jurnal komunikasi, Volume 14, Nomor 1, Oktober 2019, Hal 23-40 